\title{
Medvedjevs Rusland?
}

\section{Mette Skak}

\section{Præsidentvalget var den mindste hurdle for Medvedjev på hans vej til at blive Ruslands mæg- tigste mand. Spørgsmålet er om han får lov til at udøve den magt, som forfatningen tildeler ham}

Ud på aftenen søndag den 2. marts i år tikkede der en ikke-nyhed ind på alverdens nyhedsredaktioner: Dmitrij Anatoljevitj Medvedjev havde vundet det russiske præsidentvalg med 70,28 procent af stemmerne. Stemmeprocenten var lige så $h ø j$ : 69,8 procent - dvs. højere end ved Duma-valget i december 2007, også ganske forventeligt.

Ikke-nyheden var resultatet af et nøje aftalt spil mellem Ruslands nuværende præsident, Vladimir Vladimirovitj Putin, og Medvedjev, Putins nære ven og sparringspartner i det daglige regeringsarbejde i de sidste otte år, i nyere tid med titel af vicepremierminister samtidig med, at han er bestyrelsesformand for den magtfulde gasproducent Gazprom. Putin nominerede ham som præsidentkandidat den 10. december 2007, hvorved det forestående præsidentvalg forvandlede sig til en ikkenyhed.
Det aftalte spil og især de øvrige manipulationer af valgets konkurrenceaspekt fik OSCE til helt at droppe sin valgobservation. Medierne og eksperterne har derfor stillet skarpt på det urene trav. Derved har omverdenen overset det trods alt væsentlige faktum, at Putin overholdt forfatningen og, at selve magtskiftet den 7. maj modsat mønstret i Ruslands historie var fredeligt, næsten kedeligt.

Beretningerne om valgsvindel såsom stærkt oppustede stemmeprocenter selv i visse af Moskvas kvarterer kan heller ikke overskygge det faktum, at befolkningen i Rusland vitterlig foretrækker Medvedjev fremfor kommunisten Zjuganov, højre-ekstremisten Zjirinovskij og den ukendte demokrat Bogdanov som landets præsident. Det har alle vælgerundersøgelser forud for valget klart dokumenteret. Så Medvedjev indtræder i præsidentembedet 


\section{METTE SKAK}

med stor folkelig opbakning, selv om han ikke har tilsvarende proceduremæssig legimitet.

Derfor kan man sige, at præsidentvalget er den mindste hurdle på hans vej mod at blive den Russiske Føderations mægtigste mand. Det spørgsmål, mange nemlig stiller sig, er, om han får lov at udøve den magt, som forfatningen tildeler ham, fx kontrollen over udenrigspolitikken jævnfør paragraf 86.

Vil Putin og de øvrige silovikifolk med en fortid i de hemmelige tjenester og magtministerier - lade ham udfolde sin egen politik? Eller vil Putin, som annonceret på pressekonferencen den 14. februar, vedblive at trække i alle trådene? Hvordan vil det her forsøg på tomandsvælde overhovedet fungere indadtil i Rusland, hvor folk er vant til håndfast enmandsledelse? Har Medvedjev overhovedet et program, der adskiller sig fra Putins? Eller skal vi indstille os på mere putinisme, evt. i lidt pænere indpakning?

Overskriftens spørgsmålstegn efter Medvedjevs Rusland er ikke noget tilfælde, tværtimod.

Medvedjevs Rusland er en ligning med flere ubekendte. Men man kan også overdrive uvisheden, og under alle omstændigheder befinder Rusland sig ved nok et vendepunkt $\mathrm{i}$ landets nyere historie: Nemlig Ruslands tilbagekomst på den internationale storpolitiks arena, nu som en økonomisk stormagt på linje med andre 'emerging markets'. Det kalder man de lande, der lokker med middelklassesegmenter, altså kunder, der skal tælles i mange millioner. Ruslands middelklasse udgør mindst 30 millioner mennesker, så landet er blevet en væsentlig aktør i globaliseringen.

Analysen indledes med det sandsynlige indhold i Medvedjevs politik - vel vidende, at han bliver en præsident med en yderst selvbevidst støttepædagog. Men den magtfordeling er måske ikke så tosset, når man betænker, at Putins varslede indtræden som premierminister kan blive netop det, der holder forsmåede siloviki - eksempelvis Igor Setjin og Sergej Ivanov - på tilbørlig afstand. Medvedjev er ingen silovik, det gør ham attraktiv som Ruslands nye ansigt udadtil, men kan være en ulempe på hjemmebane, hvor magtkampen ofte er nådesløs - kto kogo (hvem vinder over hvem) som allerede Lenin sagde.

Videre belyses Ruslands nyvundne status som såkaldt BRIK-land som en af Putins sejre samt de knaster og udfordringer, der tårner sig op i horisonten, hvis Ruslands økonomiske stormagtsstatus og befolkningens begyndende velfærd skal bevares. Analysen bevæger sig derefter over i det sikkerhedspolitiske spor med afsæt i mysteriet omkring den nye russiske militærdoktrin.

Til sidst drøftes Europas bekymringer og optioner i forhold til Rusland, og der gøres status over Rusland i dag. 


\section{Hvad vil Medvedjev?}

Medvedjev, der er jurist med en ph.d. i privatret, har en mere afdæmpet og pragmatisk stil end $\mathrm{Pu}$ tin.

På en offentlig fremtræden i Krasnojarsk under 'valgkampen' advarede han mod den udbredte søgen efter en national ide og lagde luft til den megen sværmeriske udenrigspolitiske tænkning i Rusland. Det var et svirp til Putins to chefideologer, Vladislav Surkov og Vjatjeslav Nikonov, der har søsat 'det suveræne demokrati' som nationalkonservativt samlingsmærke for det nye Rusland - ikke ulig zarismens tre søjler: 'ortodoksi, enevælde og folkelig russiskhed' Medvedjevs egne prioriteter omtalte han i Krasnojarsk som fire I'er: 'institutioner, innovationer, investeringer og infrastruktur'.

Denne management-jargon kan vi lige så godt vænne os til, for det er Medvedjev i en nøddeskal. Også Putin opfører sig, som var han koncernchef for A/S Rusland: ingen pardon over for whistleblowers, de skader jo omsætningen, plus forsøg på rettidig omhu, navnlig hvad angår Ruslands dødsensalvorlige demografiske krise.

Som ægte silovik og tjekist (qua Putins fortid i efterfølgerne til Lenins hemmelige politi, tjeka'en) er der imidlertid brutaliteten til forskel mellem ham og Medvedjev. Putin kan finde på at skælde ministre og guvernører ud foran snurrende TVkameraer og bruge vendinger som 'sjakaler, der er i udlandets sold' om den helt chanceløse liberale opposition.

Medvedjev ønsker visse indenrigspolitiske omlægninger, fx respekt for privateje af virksomheder, hvor Putin har stået for en renationalisering af Ruslands energi-mastodonter ved at lade sine siloviki samt Medvedjev indtræde i ledelsen af dem. Førnævnte Setjin er både Putins vicestabschef og bestyrelsesformand for Rosneft', det store statslige olieselskab; Setjin menes at stå bag Rosneft's ikke-venlige overtagelse af oliemagnaten Mikhail Khodorskovkijs yderst rentable olieudvindingsfirma Jukos.

Som koncernchef lægger Medvedjev op til for udenrigspolitikkens vedkommende at ville prioritere udenrigsøkonomi og stabilitet højere end at udfordre omverdenen sikkerhedspolitisk. Putin, der har været den afgørende udenrigspolitiske aktør i sine præsidentperioder, har tidligere i 2008 kommenteret vredt på det, han ser som NATOs oprustning.

Det søgte Medvedjev den 26. februar at distancere sig fra ved at betone Ruslands værdifællesskab med USA, som noget, der ikke levner andet valg end samarbejde. Han lovede at samarbejde med hvem som helst, der måtte vinde præsidentvalget, men antydede en aversion mod republikaneren John McCain. 


\section{Økonomi eller sikkerhedspolitik?}

Nuvel, vi kan ikke vide, om den arbejdsdeling, Putin forestiller sig, går ud på, at han tager sig af den hårde sikkerhedspolitik og lader Medvedjev om de bløde udenrigspolitiske emner samt bøvlet med at klinke skårene. Uanset hvad, har Rusland imidlertid brug for at tage skeen i den anden hånd, præcis som Medvedjev signalerer.

Omverdenen blev foruroliget over Putins tale i München, og analytikeren Ariel Cohen sammenligner Ruslands kurs under ham med kejser Wilhelm vel at mærke efter, at han havde fyret sin udenrigspolitiske støttepædagog, nemlig Bismarck (Udenrigs, nr. 1, 2007). Men det er ikke for ingenting, at Medvedjev blev nomineret til præsidentposten af Putin. Nok taler Medvedjev om frihed - personlig frihed, pressefrihed osv. - men han har stået last og brast med Putin under hans mange stramninger, fx den yderst byzantinske NGO-lov af januar 2006.

Nok så sigende har Medvedjev været i Beograd og bekræftet Putins opbakning til Serbien i den ømtålelige sag om Kosovo. Men det kan sagtens være udenrigsøkonomen Medvedjev, der agerer, mere end sikkerhedspolitikeren.

Kremls støtte til Serbien handler nok så meget om gasledningen South Stream, der skal forsyne det sydlige Europa med gas fra Gazprom som konkurrent til den Nabucco-ledning, der skal bringe centralasiatisk gas til Europa via Tyrkiet og uden om Rusland. Så det var lige så meget formanden for Gazproms bestyrelse, ikke bare Ruslands kommende præsident, der talte ved underskrivelsesceremonien i Beograd den 26. februar. Medvedjev udnævnte da South Stream-aftalen til at udgøre fundamentet i et europæisk energisikkerheds-regime.

I det hele taget er den særlige måde, hvorpå den russiske stat er 'indlejret' i det russiske erhvervsliv, som det hedder hos globaliseringsforskere som Peter Evans, ganske interessant udenrigspolitisk set.

Netop Gazprom har udkæmpet adskillige 'gaskrige' mod Ukraine og Hviderusland, og sammenholder man det med Gazproms muskuløse adfærd over for vestlige energigiganter, bekræfter det en tese om nutidens internationale politik, som den amerikanske strategiske analytiker Edward N. Luttwak har fremsat: Verden bevæger sig fra en tilstand med klassisk militær og sikkerhedspolitisk rivalisering ('geopolitics') over mod en økonomisk rivalisering mellem staterne ('geo-economics'). Det første er kort fortalt blevet for farligt, det andet for fristende.

Samtidig tyder meget på, at Medvedjev og andre russiske udenrigspolitikere er klar over, at Rusland ofte overspiller sine geo-økonomiske trumfkort og sin øvrige udenrigspolitik. Hårde nysere som førnæunte Nikonov ved godt, at Ruslands trus- 
sel om at anerkende Abkhasien og Sydossetien som modtræk til Kosovos selvstændighed er et tveægget sværd. Derfor belærte han i Izvestija fra 8. marts 2008 i stedet sine læsere om betydningen af de bløde magtformer i international politik - som havde han læst Joseph S. Nye og fulgt kurser i det danske udenrigsministerium!

Timingen passer, for nu er valgene til både Duma og præsident ovre. Rusland behøver ikke længere at stå stejlt i sin udenrigspolitik af rene og skære valgtaktiske hensyn, som vi gang på gang har set det i $2007 \mathrm{og}$ 2008. Om nogen er Medvedjev manden, der kan tale udenrigspolitikken ned i et mere naturligt konfliktleje, mens Putin kan signalere kontinuitet indadtil.

\section{Rusland som BRIK-land}

Budskabet om, at Rusland som en anden Terminator er vendt tilbage som hovedaktør i international politik, blev bragt af Putin selv i München-talen fra 10. februar $2007 \mathrm{i}$ denne indpakning: "Fru forbundskansleren var inde på det. Indiens og Kinas samlede BNP i købekraftpariteter overgår USA's. Opgør man på samme måde BNP'et for landegruppen BRIK - Brasilien, Rusland, Indien og Kina - overgår det EU's samlede BNP. Eksperterne mener, at denne kløft vil vokse inden for en overskuelig fremtid. Der er ingen tvivl om, at de nye globale vækstcen- tres potentialer vil blive omsat i politisk indflydelse og styrke multipolariteten."

De eksperter, som Putin hentyder til, er finanshuset Goldman Sachs, der lancerede BRIK-begrebet om de nævnte fire geopolitiske og geo- $\varnothing \mathrm{ko}-$ nomiske giganter i en hyppigt citeret verdensøkonomisk prognose (Purushothaman og Sachs, "The BRICs' Path to 2050 ...", 1. oktober, 2003).

Som de stormagter, BRIK-landene er, har de meget selvbevidste regeringer, der prøver at styre og optimere det enkelte lands globalisering i tæt, korporatistisk samspil med erhvervslivet. Ruslands ovenfor beskrevne statslige monopolkapitalisme er ingen undtagelse, ejheller når det gælder satsningen på eksport og økonomisk åbenhed som kontrast til Sovjetunionens lukkethed. Den økonomiske nedsmeltning i Rusland i 1998 pustede liv i den nye hjemmemarkedsproduktion på markedsøkonomiske vilkår, og i 2000 var kurven vendt.

Der er nu stabil vækst, arbejdsløsheden er faldet til ro og reallønnen steget. Kapitalflugten er vendt til det modsatte, og udlandet begynder for alvor at investere i Rusland. 2007 slog rekorden fra året før: 121 mia. \$ i samlede russiske og udenlandske investeringer, dvs. en fordobling. Folk har fået biler, IKEA-møbler og rejser udenlands som aldrig før i Ruslands historie.

Okay, det er Putins svineheld og 


\section{METTE SKAK}

ikke hans fortjeneste, at både olieog gasprisen på verdensmarkedet er gået støt opad i begge hans præsidentperioder. Men han har suppleret med skattereformer og genoprettet statens funktionsevne indadtil i Rusland og derved skabt den ro og stabilitet, som russerne har hungret efter oven på Jeltsin-årenes kaos. Metoderne minder om Peter den Store - tænk på de syv superguvernører, Putin indsatte for at ånde Ruslands regionale guvernører, republikpræsidenter og lokalforvaltninger tungt i nakken. Dette centralistiske tiltag kan imidlertid godt have styrket fremfor svækket menigmands retsstilling, selv om korruption og embedsmisbrug forbliver et enormt problem.

Fortidens hypermilitarisme plager stadig Rusland: våbenindustrien er stort set ene om at være højteknologisk; den beskæftiger over halvdelen af landets videnskabsmænd og -kvinder og står for over 70 procent af vidensproduktionen (se Blanks artikel i Problems of Post-Communism, nr. 1, 2008). Men i dag befinder forsvarsudgifterne sig på et anderledes jordnært niveau: under fem procent af BNP siden år 2000, hvor CIA førhen talte om en rustningsbyrde på 25-30 procent af den sovjetiske samfundshusholdning. Faktisk ryster den russiske rustningsøkonom Vitalij Shlykov på hovedet, når talen falder på, om CIA's eller deres amerikanske rivalers estimater var korrekte. Det rigtige tal, som de aldrig fandt frem til, siger han og slår en skraldlatter op - det var sgu 100 procent! Han understreger, at hovedtendensen er en de-militarisering af økonomien, ikke oprustning, selv om Putin kaster lidt lunser ud i form af enkeltstående prestigeprojekter (personligt interview, Moskva, januar 2008).

\section{WTO}

En anden knast i forhold til Medvedjevs strategi med innovationer, investeringer og infrastruktur er, at Rusland som den eneste af BRIKstormagterne ikke er medlem af WTO, sådan som Ukraine og visse andre post-sovjetiske lande er. Så længe Rusland er en petrostat, der bare skal leve af olie og gas, er problemet ikke så stort. $\mathrm{Og}$ dog. For skal olie- og gaseventyret fortsætte, vil det kræve enorme investeringer i udvindings- og forsyningsinfrastruktur.

Her er Putins re-nationaliseringer og Gazproms muskuløse forhandlingsstil problematisk uanset, at investeringerne begynder at vælte ind. Et WTO-medlemskab vil afstive Ruslands ry som marked og pålidelig samarbejdspartner på en måde som ingen reklamekampagne kan. Hertil kommer den bagvedliggende vision om helt at bryde med energieksportens dominans af udenrigshandelen, som man finder i mange af Putins taler og hos Medvedjev. Visionen vil falde til jorden, hvis Rusland vedbliver at stå uden for WTO. 
WTO-medlemskabet har længe været en mærkesag for Kreml, men man er tilsyneladende løbet sur i de komplekse optagelsesforhandlinger og siger nu, at det ikke er så vigtigt stolthed spiller tydeligvis ind. Ikke mindst de russiske landmænd frygter konkurrencen fra udlandet, og WTO-medlemskabet vil givetvis gøre livet surt for de mange mindre konkurrencedygtige producenter i Rusland. Måske har Rusland ligefrem brug for WTO som stressfaktor: Stik mod normal praksis har fx IKEAs afdelinger i Rusland opgivet at have lokale møbelfabrikker som underleverandører, da de ikke kan leve op til IKEAs produktstandarder.

Under overskiften innovation gemmer der sig ifølge Medvedjev en satsning på informationsteknologi (IT). I teorien ligger det lige til højrebenet, når det drejer sig om Rusland. Landet har fået en hær af eminente matematikere, naturvidenskabsfolk og ingeniører i arv fra Sovjetunionen - sammenlagt ca. en halv million sådan menneskelig kapital, og Rusland vedbliver at være det europæiske land, der producerer langt det største antal højtuddannede.

Godt 20 procent af den voksne befolkning har taget internettet til sig som seriøs kilde til information og andre formål, for RuNet, som det hedder, er ikke underlagt statslig censur (modsat situationen i Kina). I løbet af 1990'erne voksede der en kreativ russisk IT-industri frem, og software-eksporten er faktisk Rus- lands mest konkurrencedygtige på verdensmarkedet. IBM satser nu på de russiske matematikeres kunnen og har åbnet et udviklingslaboratium i Moskva.

Men russerne kan på ingen måde hamle op med inderne som software-eksportører. Ifølge data fra D.J. Peterson, Russia and the Information Revolution (RAND, 2005) udgjorde den russiske IT-eksport i 2003 højst $1 / 30$ af den indiske, som lever højt på, at den indiske elite taler engelsk på modersmålsniveau som Indiens arv fra tiden som britisk koloni. Nummer to og tre i rækken af ITeksportgiganter er de lige så professionelt engelsktalende lande Irland og Israel.

Derfor peger russiske og vestlige analytikere på Ruslands indbyggede sprogproblem, hvortil kommer de nationalistiske politikeres og til tider myndighedernes IT-fjendske holdninger. Hvis Rusland skal udnytte sine enestående potentialer på området, er det nødvendigt, at der seriøst udvises åbenhed, globalisering og professionalisme over for omverdenen.

Imidlertid har de politiske konjunkturer under Putin stimuleret det stik modsatte: xenofobi kulminerende i hate crimes mod sagesløse mørklødede udlændinge. For det er ikke bare styrvolterne i Putins ungdomsbevægelse Nashi, men ham selv, der har hetzet mod de liberale og mod Vesten og bidraget til såvel forråelse som fordummelse. På den 
baggrund virker Medvedjevs og $\mathrm{Pu}-$ tins egne højtflyvende tanker om Rusland som 'ide-land' fremsat på XI St Petersburg Economic Forum i 2007 ude af trit med virkeligheden. Karakteristisk nok foreslog han i trontalen af 26. april 2007 at skabe en national fond for det russiske sprog til støtte for russiskundervisning og studiet af russisk litteratur verden over.

Flere iagttagere vurderer, at festen meget vel kan være ved at slutte: Oven på de otte fede år med Putin vil følge nogle om ikke magre, så $\mathrm{i}$ hvert fald udfordrende år for putinismen. Inflationen (p.t. 12 procent) og navnlig prisstigningerne på dagligvarer giver murren i krogene, og mange russere er betænkelige ved den magtens arrogance, der hersker i Kreml indadtil som udadtil.

Ganske vist har Rusland lige nu en enestående chance for at indhente det forsømte og opbygge infrastrukturen, men stadig er omverdenens konstruktive medspil kritisk af hensyn til at opnå investeringer der, hvor behovet er akut. Imidlertid er Putins anseelse selv i det ruslandsvenlige Tyskland styrtdykket til et niveau på linje med USA's nuværende præsident George W. Bush.

Det er problematisk, for Vesten er simpelt hen livlinen til ikke bare materiel højteknologi, men også politisk-institutionel teknologi samt den kulturelle og sikkerhedspolitiske europæiske identitet, som russerne ikke er et sekund i tvivl om, den dag de bliver tvunget til at vælge mellem deres forankring i Europa eller Asien.

Dermed er vi ovre i sikkerhedspolitikken.

\section{Militærdoktrinen, der døde}

For Rusland er der enorm prestige forbundet med at følge USA's eksempel på det udenrigs- og sikkerhedspolitiske område. Man har skabt et nationalt Sikkerhedsråd og lancerer jævnligt sikkerhedspolitiske programerklæringer i stil med USA's nationale sikkerhedsstrategier.

Derfor forlød det længe, at der i løbet af 2007 ville komme en ny russisk militærdoktrin som afløser for det store doktrin-kompleks fra 2000 og den midlertidige opfølgning af 2. oktober 2003 (Aktual'nye zadatji razvitija Vooruzjonnykh sil Rossijskoj Federatsii; se de Haas i Baltic Defence Review, nr. 12, 2004). Men 2007-doktrinen kom aldrig, og de Kreml-insiders, jeg har talt med, bliver forlegne, når man spørger til den. Ved nærmere eftertanke er det ikke så afgørende for os at have en militærdoktrin, lyder svaret.

Forklaringen på den overraskende vending, som sagen har taget, ligger antagelig i de signaler om doktrinens indhold og sigte, der er sluppet ud.

Således kunne man i Nezavisimaja Gazeta den 25.-26. august 2006 læse, at nu hvor Ruslands omstilling fra 
diktatur til demokrati er ovre, er tiden inde til ikke bare at specificere trusler, men også at udpege den Russiske Føderations allierede og fjender i en evt. krigssituation.

Ordren om at udarbejde en ny doktrin kom fra daværende forsvarsminister Sergei Ivanov, der lagde arbejdet i hænderne på udvalgte officerer fra Generalstaben og embedsmænd fra Sikkerhedsrådet. Avisens kilde til arbejdet med doktrinen var den åbenmundede og fritænkende generalmajor Jurij Kirsjin, der blandt andet har skrevet en sønderlemmende kritik af Stalins forsvarspolitik før og under Anden Verdenskrig, men alligevel bevaret sin stilling ved Generalstaben åbenbart som medforfatter til doktrinen.

Kirsjin understregede den afgørende betydning af at opregne hhv. venner og fjender, fordi Rusland kan være allieret med nogle stater $i$ bestemte krige og konflikter, men med andre i andre typer konflikter. Derved lagde han op til almindelig statsræson, hvor stater ikke har permanente venner, kun permanente interesser.

Han gjorde det klart, at Rusland bør allierede sig med USA og NATO i kampen mod terror og mod uansvarlige diktatorer, der truer omverdenen med masseødelæggelsesvåben - velsagtens en hentydning til Irans leder Mahmoud Ahmajinedad og Nordkoreas Kim Jong II! Omvendt mente Kirsjin, at Rusland kunne blive USA's og NATOs modstan- dere i en evt. krig om verdensordenen.

Selv med denne tilføjelse forekommer det, at Kirsjins udlægning af teksten har placeret ham på kollisionskurs med de dominerende ærkekonservative strømninger i det russiske militærs top. Selv om 2003papiret og almindelig sund fornuft tilsiger, at USA og NATO ikke er fjender af Rusland og derfor ikke bliver landets modstandere i en evt. storkrig, har toneangivende russiske militære topfolk mere end svært ved at slippe fortidens fjendebillede. Kirsjin ville nemlig omdefinere Ruslands syn på henholdsvis retfærdige og uretfærdige krige og sætte krigen mod terror i centrum som det 21 . årh.s svøbe - og samtidig bekrige Ruslands egen falske patriotisme og falske fjendebilleder.

Sagt på en anden måde har de mere sikkerhedspolitisk fremsynede og ansvarlige kræfter i Kreml besluttet at lægge låg på sagen formentlig for ikke at udstille og forpligte Rusland på de oldnordiske og modproduktive fjendebilleder, der trives i det russiske officerskorps og dets støtter i Dumaen samt hos eurasiater som Aleksandr Dugin.

Ergo skal man ikke overdrive den indflydelse, som de sværmeriske chauvinister i Rusland egentlig har, når det kommer til det operationelle niveau af russisk sikkerhedspoltik. For ganske vist er munden hermed blevet lukket på Kirsjin, men så sandelig også på hans modstandere. 


\section{Europas bekymringer og optioner}

Der tales og skrives meget om EU's svaghed og splittelse, men realiteten er, at ikke mindst Putins og Gazproms fremfærd har skabt nyt fodslag i EU for at modvirke det, man opfatter som russisk afpresningspolitik. Således har EU vedtaget et overordentlig ambitiøst program for at sænke $\mathrm{CO}_{2}$-udslippet, som i sin effekt bliver et særdeles mærkbart Ruslandspolitisk tiltag - det vil generobre meget af EU's handlefrihed. For Europas afgørende og generelt dårligt udnyttede ruslandspolitiske option er og bliver den fælles beslutsomme optræden via $\mathrm{EU}$, som påpeget i det ruslandsstrategiske papir, som tænketanken European Council on Foreign Relations debuterede med den 7. november 2007.

Der går simpelt hen en lige linje fra de enkelte EU-landes - inklusive Danmarks! - fuldtonede opbakning bag EU til Vestens muligheder for normativt at påvirke Rusland i retning af demokrati, retsstat og fredelighed.

Det skyldes, at EU endnu mere end NATO ser sig selv som et værdifællesskab baseret på Europarådets høje standarder for menneskerettigheder jf. Lissabontraktaten. Det gør EU til en krumtap for den normativt ambitiøse vestlige ruslandspolitik ligesom Europarådet selv; her skal man jo huske, at Rusland er medlem af Europarådet og er blevet pålagt at ophæve dødsstraffen.
Siden 1999 har den russiske stat ikke foretaget en eneste henrettelse.

Andrei Tsygankov, en russisk politolog med speciale i Ruslands udenrigspolitik ser Vestens anerkendelse af Rusland som determinant for magtforholdet mellem de liberale og de anti-liberale kræfter i Rusland, en plausibel tese. Men denne indsigt betyder ikke, at Vesten ukritisk skal stryge Rusland med hårene, tværtimod må man spille på, at Ruslands selverkendte europæiske identitet indebærer en forpligtelse på nutidens europæiske standarder. Grunden til, at Kina og Indien får en blidere medfart er jo, at de vedgår sig en asiatisk identitet.

Endvidere må russerne bringes til at indse, at de får megen særbehandling allerede eksempelvis via Ruslands præmature optagelse i G8.

Selv om de russiske magthaveres egen stil er at give den som machoer og machiavellister er de bestemt ikke upåvirkede af EU som forbillede. Det gælder integrationen indadtil i EU, som har meget mere betydning i dagligdagen end NATOs udvidelse af medlemskredsen, og det gælder EU's udpræget bløde magt som aktør i international politik jf. Nikonovs føromtalte besyngelse af denne magtform.

Samtidig skal man ikke være blind for to andre forhold: Trods Ruslands generelle hetz mod NATO er Kreml påfaldende afdæmpet i sin kritik af NATOs militære operation i Afghanistan. 
ISAF-operationen løser nemlig et akut sikkerhedsproblem for Rusland. Derfor forlyder det nu, at NATO og Rusland vil til at samarbejde tæo om at få forsyninger til ISAFstyrken frem gennem SNG-territorium, dvs. Usbekistan og Kasakhstan, så NATO ikke behøver at forlade sig på det notorisk ustabile Pakistan.

Budbringeren af denne nye drejning i russisk NATO-politik er en velkendt høg i russisk sikkerhedspolitik, nemlig Ruslands nye NATOambassadør Dmitrij Rogozin (Financial Times, 7. marts, 2008). Det siger noget om den gensidige afhængighed og tillid mellem Rusland og NATO, som der faktisk er at spille på nedenunder overfladen af kold krig og russisk udvidelseshysteri.

Det andet forhold, der påkalder sig opmærksomhed, er EU's samtidige offentliggørelse af et alarmistisk strategi-papir om udsigten til kold krig i de arktiske egne som følge af klimaændringerne. Ophavsmændene var EU's Høje Repræsentant for den fælles udenrigs- og sikkerhedspolitik Javier Solana, og udenrigskommissæren Benita Ferrero-Waldner (The Guardian, 10. marts, 2008).

Blandt andet slog de ned på Kremls demonstrative plantning af det russiske flag på Nordpolens havbund $i$ august 2007 som en begivenhed med "mulige konsekvenser for international stabilitet og europæiske sikkerhedsinteresser".

Det er lige præcis udsigten til 'geo-økonomi' i Arktis, der foruroliger EU: Intens rivalisering om ressourcer og handelsruter efterhånden som Nordvestpassagen, senere Nordøstpassagen bliver sejlbare som alternativ til de lange ruter gennem Suezkanalen og Malaccastrædet eller Panama-kanalen. Det manifest for et nyt NATO, der skal fremlægges på topmødet i Bucharest i april 2008, lufter de samme bekymringer affødt af Ruslands offensive fremfærd $\mathrm{i}$ international politik (sammesteds).

Med andre ord trækker der skyer op i horisonten for Rusland - økonomisk og sikkerhedspoltisk. Det er imidlertid ikke noget dårligt tegn. Rusland er givetvis farligere, når landet ikke får kritisk modspil. Alt tyder nemlig på, at saglig, kritisk dialog samt en beslutsom og klar politik fra omverdenens side gør indtryk i Kreml.

På en måde er vores stærkeste våben en fordomsfri, seriøs ruslandsekspertise - for kritikerne af vestlig ruslandspolitik har desværre ret, når de peger på den overfladiskhed og inkonsekvens, der ofte præger Vestens syn på Rusland.

\section{Rusland anno 2008 og frem}

Det billede, der aftegner sig, er et Rusland som nok afstiver sig med koldkrigeriske manøvrer og udviser foruroligende tendenser i sin indenrigspolitik, men som ingenlunde er uden for pædagogisk rækkevidde. 


\section{METTE SKAK}

Under den kølige og blankpolerede overflade som BRIK-stormagt ser det ud til, at beslutningstagereliten er ved at få et mere realistisk syn på, hvilke svagheder og faldgruber, der lurer.

Derfor er det ikke sikkert, at det vil gå Rusland så galt som spået af Harvey Balzer (se Post-Soviet Affairs, nr. 3, 2005). Han parallelliserer til Spaniens katastrofalt ensidige og dårligt forvaltede grundlag for sin opstigning til verdensmagt i 1500 tallet på basis af sølv og guld -i Ruslands tilfælde gas og olie - en opstigning, der som bekendt endte brat med den Uovervindelige Armadas forlis ud for Skotlands kyst. Men skal Rusland klare skærene for nu at blive i billedet, er det afgørende, at den bølge af vækst, som Rusland nu rider på, administreres klogt og fremsynet og det vil nødvendigvis sige i tæt samspil med Vesten, i al fald ikke det modsatte.

Valget af Medvedjev til landets nye præsident er ikke nogen dårlig begyndelse. Han signalerer åbenhed og saglighed iblandet loyalitet over for den kurs, som Putin har udstukket. Det betyder, vi ikke kommer til at stå over for et liberalt, individ-orienteret Rusland sådan som vi forstår begrebet liberal. Scenariet bliver snarere et Rusland, hvor putinismen har fået et tiltrængt tilskud af realitetssans, dvs. et knap så bøst Rusland. Så må man heller ikke glemme, at Rusland er et land, der ofte byder på overraskelser - både af den ubehagelige og den rare slags. Det ved eliten alt om, det er en af grundene til, at den ikke har travlt med at ophæve moratoriet på dødsstraffen: Det er dens livsforsikring.

Hvad angår Putin som den onde zar og Medvedjev som den gode, sådan som det fremstår her, vil jeg slutte med at genopfriske mindet om Aleksandr Lebed, der omkom i 2002 og derfor aldrig blev præsident for Rusland, som mange i Vesten dengang håbede på. Menneskerettighedsaktivisten Aleksandr Sungurov fra Sankt Petersborg bekræfter, at Lebed før sin død var eneste realistiske alternativ til det Putin-scenario, vi har set.

Men med Lebed som præsident ville det være gået langt værre, insisterer han: Putins rolle som bestyrer af den mere autoritære fase af systemskiftet er langt fra det værste, der kunne være overgået os! (Russia Profile, 6. marts 2008).

Mette Skak er lektor ved Institut for Statskundskab, Århus Universitet. 